\title{
The intensity evaluation research of equipment and manufacturing industry in Hebei province
}

\author{
Jie Wan, Li Geng* \\ Hebei University of Technology, Economic Management Institute, Tian Jin, Bei Chen District \\ *Corresponding author: Li Geng,master,1326914863@qq.com
}

\begin{abstract}
:
Equipment and manufacturing industry takes a large proportion in national economy and technical equipment of national defense construction. Due to the complexity of its production process and the close relation between upstream and downstream ofenterprises, the form of industrial cluster benefits to the development of equipment and manufacturing industry in Hebei Province. Equipment and manufacturing industry is the pillar industry in Hebei Province, which plays a crucial role in the economic development of Hebei Province. So measuring the degree of equipment and manufacturing industry cluster in Hebei Province clearly is particularly important. During the process of evaluating the equipment and manufacturing industry through the method of location quotient and industry concentration in Hebei Province, we can see that the equipment and manufacturing industry in Hebei Province is too scattered, and then make corresponding suggestions to the development ofequipment and manufacturing industry cluster in Hebei Province.
\end{abstract}

Key words:equipment and manufacturing industry;the method of location quotient; the method of industrial concentration

\section{Introduction}

Equipment and manufacturing industry is responsible for providing production technology and equipment and manufacturing for the national economy and national defense construction, and it's the core sector of the manufacturing industry. Because of its long chain and complex links in manufacturing, obvious cluster characteristics, and the complex constituent factors, it is most suitable for the development of industrial clusters ${ }^{1}$. With the continuous expansion of the equipment and manufacturing industry cluster in Hebei Province, 32 provincial industrial clusters are identified, such as Baoding. China Electeicity Valley, Light Automobile City in North China, Qinhuangdao Major Equipment and Export Base, Caofeidian New District and other provincial industrial agglomeration area $^{2}$. Industrial clusters begin to take shape. The development of equipment and manufacturing industry cluster has played a strong guiding and promoting role in the development of regional economy in Hebei Province.

Most of the industrial clusters in Hebei Province only share the infrastructure in the form, but the industry is not relevant, which to a certain extent hindered the gathering of upstream and 
downstream enterprises of equipment and manufacturing industry in Hebei Province. Upstream and downstream enterprises of equipment and manufacturing industry mostly provide products for a number of equipment and manufacturing enterprises, so the consciousness of getting closer to the high value-added enterprises is weak. It is difficult to form a scale advantage, resulting in the equipment and manufacturing industry concentration is low in Hebei Province.

\section{Literature review}

Zhonghua Zhao and Yunquan $\mathrm{Hu}{ }^{3}$ use the two indicators of location quotient and industrial concentration taking the development status of equipment and manufacturing industry cluster in Liaoning Province as the research object and measuring the degree of industrial cluster in the equipment and manufacturing industry in this region. In comparison with other industries in the region, we find out the advantages and disadvantages and then put forward the corresponding suggestions. GuoyiXiu and Meng $\mathrm{Fu}{ }^{4}$ use the method of location quotient to measure the degree of equipment and manufacturing industrial concentration in Heilongjiang Province, and put forward the suggestion of creating environmental integration , increasing the cluster entry barriers and reducing the internal barriers. Zeyu Wang and ZenglinHan ${ }^{5}$ use the method of location quotient, Lorenz curve, centralized index and so on to measure the status of the cluster of equipment and manufacturing industry in Shenyang, and conclude that although the equipment and manufacturing industry in Shenyang has certain advantage in scale, but there is no formation of various types of enterprises in close cooperation and division of labor network system, and it can't play the real advantage of cluster. Haonan Duan ${ }^{6}$ uses themethod of system dynamics to analyze the problem in equipment and manufacturing cluster development in Harbin, and identifies the main factors affecting its development, and then put forward the solution to the problem and the development strategy. There are many ways to measure the degree of concentration of the industry, and the most commonly used is the Herfindal-Hauschmann Index, location quotient and industrial concentration method. Herfindal-Hochman index have higher requirements for data, so the operability is not strong. In regional economics, location quotient isusually used to judge whether an industry constitute the region specialized departments or not. As thedata collection of industrial concentration method is relatively simple with strong operability, it is widely used in industrial concentration measurement.

\section{Aggregation degree analysis}

\subsection{Cluster level analysis}

The location quotient is a quantitative tool for the efficiency and benefit analysis of the industry. It is a common method of cluster identification and is used to measure the relative concentration of an aspect of an industry in a specific area ${ }^{7}$ 
Its indicator is defined as: $L Q_{i j}=\frac{\frac{x_{i j}}{\sum_{i} x_{i j}}}{\sum_{i} x_{i j} / \sum_{i} \sum_{j} x_{i j}}$.

Where $\mathrm{i}$ is the $\mathrm{i}$-th industry, $\mathrm{j}$ is the $\mathrm{j}$-th region, $x_{i j}$ is the output indicator of the $\mathrm{i}$-thindustry of the $\mathrm{j}$-th region, $\sum_{i} x_{i j}$ is the total output value of the $\mathrm{j}$-th region, and $\sum_{j} x_{i j}$ is the total output value of the i-th industry in the country. $\sum_{i} \sum_{j} x_{i j}$ is the total output value of the various industries. When $L Q_{i j}>1$, it indicates that the specialization level of the i-th sector in the j-th region is higher than the national average. When $L Q_{i j}<1$,it indicates that the average level of the i-th sector in the $\mathrm{j}$-th region is lower than the national average level. When $L Q_{i j}$ $=1$,it indicates that the professional level of the i-sector in the j-region is equivalent to the national average level. The larger the value of $L Q_{i j}$, the higher the level of specialization ${ }^{7}$

\subsubsection{Comparative analysis of the degree of aggregation among equipment andmanufacturing} industry with other external industry in Hebei Province

Adopt the industry of Coal mining and election industry, ferrous metal mining industry, textile industry, electricity, heat production and supply industry, which rank top in Hebei Province, to highlight the advantages and disadvantages of equipment and manufacturing industry. The main economic indicators including the number of business units, the main business income, total assets and total profit are used to reflect the size of the industry and profitability and location quotient method is used to analyze the degree of its concentration, the results shown in Table 1.

It can be seen from Table 1 that equipment and manufacturing industry, coal mining and washing industry, textile industry, electric power, heat production and supply industry this four industries industrial specialization are lower than the national average level. And the black metal mining industry is higher than the national average in the total assets and profitability. Although the equipment and manufacturing industry higher than the black metal mining industry in enterprise aggregation aspect, the main business income and profit are lower than the national average, and lower than the black metal mining industry, which shows that although the equipment and manufacturing industry has a little advantage in the industrial agglomeration, but there is still a lot of room for development. Black metal mining industry is on the top of the scale, on the basis of which the level of business units gathered below the equipment and manufacturing industry, which shows that black metal mining industry is not dependent on industrial park so much. Equipment and manufacturing industry's professional 
level is close to the level of coal mining and washing industry, textile industry, electricity, heat production and supply industry, and the level of specialization is similar, but in the business unit, the equipment and manufacturing industry is far higher than the other three industries, which shows that equipment and manufacturing industry in Hebei Province is more dependent on the industrial park than the other three industries.

Table 1: The results of location quotient analysis of the major economic indicators' of some top industries in Hebei Province in 2015 Industry category

\begin{tabular}{|r|r|r|r|c|}
\hline $\begin{array}{c}\text { Major economic } \\
\text { indicators }\end{array}$ & $\begin{array}{c}\text { Number } \\
\text { of business } \\
\text { units }\end{array}$ & $\begin{array}{c}\text { Main } \\
\text { business income }\end{array}$ & Total assets & Total profit \\
\hline $\begin{array}{c}\text { Equipment and } \\
\text { manufacturing }\end{array}$ & 0.9485 & 0.6417 & 0.7147 & 0.7367 \\
\hline $\begin{array}{c}\text { Coal mining and } \\
\text { washing industry }\end{array}$ & 0.1019 & 0.9915 & 0.8719 & -1.4659 \\
\hline $\begin{array}{r}\text { Black metal } \\
\text { mining industry }\end{array}$ & 0.8834 & 3.6454 & 4.9583 & 8.2166 \\
\hline $\begin{array}{r}\text { Textile industry } \\
\text { Electricity, heat }\end{array}$ & 0.1563 & 0.6567 & 0.7519 & 0.9554 \\
\hline production and supply & 0.2068 & 0.7367 & 0.7635 & 0.7776 \\
\hline
\end{tabular}

Source: Based on the China Statistical Yearbook 2016 and the Hebei Statistical Yearbook 2016

3.1.2 Comparative analysis of the degree of aggregation among internal industry of equipment andmanufacturing industry in Hebei Province

This paper makes a comparative analysis of the current industrial concentration development in internal industry of equipment andmanufacturing industry in Hebei Province, and chooses the four major economic indicators in the eight categories of equipment and manufacturing industry in Hebei Province including the number of enterprises, the main business income, the total assets and the total profit of the enterprises, which can be collected the most recent year of 2015. The location quotient method is used to measure and analyze the concentration of industrial concentration, the result is shown in Table 2. 
Table 2-The main economic indicators' analysis results of eight major sectors in equipment and manufacturing industry by the method of location quotient in Hebei Province in 2015

\begin{tabular}{|c|c|c|c|c|}
\hline $\begin{array}{l}\text { Industry category } \\
\text { Major economic } \\
\text { indicators }\end{array}$ & $\begin{array}{l}\text { Number of } \\
\text { business units }\end{array}$ & $\begin{array}{c}\text { Main } \\
\text { business income }\end{array}$ & Total assets & Total profit \\
\hline Metal products industry & 2.3405 & 2.5836 & 1.7336 & 2.0910 \\
\hline $\begin{array}{l}\text { General equipment and } \\
\text { manufacturing industry }\end{array}$ & 1.3088 & 0.8722 & 0.5718 & 1.0222 \\
\hline $\begin{array}{l}\text { Special equipment and } \\
\text { manufacturing industry }\end{array}$ & 1.4230 & 1.2177 & 1.0060 & 1.6081 \\
\hline $\begin{array}{l}\text { Automotive } \\
\text { Manufacturing }\end{array}$ & 0.7403 & 0.5921 & 0.7761 & 0.6213 \\
\hline \begin{tabular}{|c|} 
Railways, ships, \\
aerospace and other \\
transportation equipment and \\
manufacturing
\end{tabular} & 0.6399 & 0.5678 & 0.6394 & 0.9601 \\
\hline $\begin{array}{r}\text { Electrical machinery and } \\
\text { equipment and manufacturing }\end{array}$ & 0.7843 & 0.6916 & 0.7102 & 0.6108 \\
\hline $\begin{array}{c}\text { Computer, } \\
\text { communications and other } \\
\text { electronic equipment and } \\
\text { manufacturing }\end{array}$ & 0.1675 & 0.0992 & 0.2735 & 0.2407 \\
\hline $\begin{array}{c}\text { Instrumentation } \\
\text { manufacturing industry }\end{array}$ & 0.4903 & 0.3209 & 0.3683 & 0.5224 \\
\hline
\end{tabular}

Source: Based on the China Statistical Yearbook 2016 and the Hebei Statistical Yearbook 2016.

As can be seen from Table 2, among the eight categories of industries of equipment and manufacturing industry inHebei Province, general equipment and manufacturing and special equipment and manufacturing industry have begun to take the advantage of scale, but the degree of industrial agglomeration is inferior to the metal products industry, which shows that general equipment and manufacturing and special equipment and manufacturing industry still have the room forimprovement, and these three industries are superior to the national average. Electrical machinery and equipment and manufacturing industry is slightly lower than the automobile manufacturing industry in the total amount of assets, but the main business income is higher than the automobile manufacturing industry, and the gap in the total profit is very small, indicating that the degree of agglomeration of the electrical machinery and equipment and manufacturing industry is better than the automobile manufacturing industry, and have the advantage in size than the automobile manufacturing industry.

\subsubsection{Theanalysis of equipment and manufacturing cluster development trend in Hebei} Province

This paper analyzes the development trend of the current industry concentration of the eight 
categories of equipment and manufacturing internal industries in Hebei Province, and chooses four major economies index including the number of enterprises,the main business income, the total assets and the total profit ofthe eight categories of equipment and manufacturing industry in Hebei Provincefrom 2013 to 2015, using themethod of location quotient to analyze the development trend of its industry concentration, the result is shown in Table 3.

Table 3- The main economic indicators' analysis results of eight major sectors in equipment and manufacturing industry by the method of location quotient in Hebei Province from 2013 to 2015

\begin{tabular}{|c|c|c|c|c|c|}
\hline Industry category & Years & Number of & Main & Total & Total \\
\hline \multirow{3}{*}{$\begin{array}{l}\text { Metal products } \\
\text { industry }\end{array}$} & 2013 & 1.6143 & 1.6228 & 1.7268 & 1.7051 \\
\hline & 2014 & 1.6576 & 1.7149 & 2.6214 & 1.8121 \\
\hline & 2015 & 2.3405 & 2.5836 & 1.7336 & 2.0910 \\
\hline \multirow{3}{*}{$\begin{array}{l}\text { General equipment } \\
\text { and manufacturing } \\
\text { industry }\end{array}$} & 2013 & 0.9503 & 0.6275 & 0.5284 & 0.7849 \\
\hline & 2014 & 0.9452 & 0.6669 & 0.5507 & 0.8711 \\
\hline & 2015 & 1.3088 & 0.8722 & 0.5718 & 1.0222 \\
\hline \multirow{3}{*}{$\begin{array}{l}\text { Special equipment } \\
\text { and manufacturing } \\
\text { industry }\end{array}$} & 2013 & 1.2296 & 0.8861 & 0.9519 & 1.2111 \\
\hline & 2014 & 1.1781 & 0.9162 & 0.9289 & 1.1393 \\
\hline & 2015 & 1.4230 & 1.2177 & 1.0060 & 1.6081 \\
\hline \multirow{3}{*}{$\begin{array}{l}\text { Automotive } \\
\text { Manufacturing }\end{array}$} & 2013 & 0.9596 & 0.6681 & 0.6631 & 0.8382 \\
\hline & 2014 & 0.9265 & 0.6972 & 0.7081 & 0.7948 \\
\hline & 2015 & 0.7403 & 0.5921 & 0.7761 & 0.6213 \\
\hline \multirow{3}{*}{$\begin{array}{l}\text { Railways, ships, } \\
\text { aerospace and other } \\
\text { transportation equipment } \\
\text { andmanufacturing }\end{array}$} & 2013 & 0.7272 & 0.5906 & 0.5301 & 0.7933 \\
\hline & 2014 & 0.8063 & 0.6749 & 0.6972 & 1.0449 \\
\hline & 2015 & 0.6399 & 0.5678 & 0.6394 & 0.9601 \\
\hline \multirow{3}{*}{$\begin{array}{l}\text { Electrical machinery } \\
\text { and equipment and } \\
\text { manufacturing }\end{array}$} & 2013 & 0.8280 & 0.6239 & 0.7456 & 0.2797 \\
\hline & 2014 & 0.8265 & 0.6894 & 0.7119 & 0.2251 \\
\hline & 2015 & 0.7843 & 0.6916 & 0.7102 & 0.6108 \\
\hline \multirow{3}{*}{$\begin{array}{c}\text { Computer, } \\
\text { communications and other } \\
\text { electronic equipment and } \\
\text { manufacturing }\end{array}$} & 2013 & 0.3128 & 0.1114 & 0.1901 & 0.2259 \\
\hline & 2014 & 0.3165 & 0.1213 & 0.2094 & 0.3139 \\
\hline & 2015 & 0.1675 & 0.0992 & 0.2735 & 0.2407 \\
\hline \multirow{3}{*}{$\begin{array}{c}\text { Instrumentation } \\
\text { manufacturing industry }\end{array}$} & 2013 & 0.5353 & 0.2308 & 0.3357 & 0.3483 \\
\hline & 2014 & 0.5558 & 0.2402 & 0.3131 & 0.3803 \\
\hline & 2015 & 0.4903 & 0.3209 & 0.3683 & 0.5224 \\
\hline
\end{tabular}

Source: According to "China Statistical Yearbook" $2014 \sim 2016$ and calculating the related data "Hebei Statistical Yearbook" 2014 2016. 
From Table 3, we can see that the development of general equipment and manufacturing industry and special equipment and manufacturing industry with LQ greater than 1 has begun to take the advantage of scale. The total profit of the metal products industry has increased year by year, and the total LQ of value of assets has increased and then decreased, which shows that after getting the scale advantage, the metal products industry gradually increases capital utilization. General equipment and manufacturing industry keeps increasing in the number of business units and the total steady in profits, at the same time, the total capital has maintained a certain level, indicating that the speed of capital turnover and the improvement of capital utilization. Special equipment and manufacturing industry obtains a certain scale of income, and then maintain the scale of income, at the same time, the distribution of enterprises is increasingly dispersed, indicating that the development of special equipment and manufacturing is no longer just rely on the geographical location of the concentration, which can be facilitated the traffic to make up.

Scale income of automobile manufacturing, rail, ship, aerospace and other transportation equipment and manufacturing, electrical machinery and other equipment and manufacturing industryis slightly lower than the national average, whose LQ is less than 1 , and the automobile manufacturing industry has justget lower production costs through the construction of different plants, increasing investment at the same time, and the production units is more and more scattered, but with the plant construction perfectinglater, it will achieve a higher scale benefitscertainly. The industry scale of computer, communications and other electronic equipment and manufacturing and instrumentation manufacturing is far lower than the national average, so the industrial concentration advantage is not highlighted.

\subsection{Analysis of industrial concentration}

Industrial concentration is a concept that characterizes the structural traits of industrial markets and the control of large enterprises. It is usually expressed as the proportion of some top enterprises accounting the whole industryin certain indicators. The greater the ratio,

the higher the industry concentration is ${ }^{8}$. The formula is: $C R_{n}=\frac{\sum_{1}^{n} X_{i}}{\sum_{1}^{N} X_{i}}$

Among them, $C R \mathrm{n}$ is the market concentration of the top $\mathrm{n}$ enterprises in the $\mathrm{X}$ industry. $X_{i}$ is the indicator of the main business income, total assets and industrial added value of the i-th enterprises of the $\mathrm{X}$ industry. $\sum_{1}^{\mathrm{n}} X_{i}$ is the sum of some main business income of $\mathrm{n}$ firms, total assets, industrial added value and other indicators; $\mathrm{N}$ for all enterprises. CR2, CR4 and CR8 are calculated for the main business income. 


\subsubsection{Analysis on the concentration degree of equipment and manufacturing industry in Hebei}

\section{Province}

This paper analyzes the current industry concentration and its development trend of the internal equipment and manufacturing industry in Hebei Province and selects the sales income of the eight categories of equipment and manufacturing industry in Hebei Province from 2012 to 2015, and uses the industrial concentration method to calculate the CR2, CR4 and CR8, and then analyzes its industrial concentration development trend. The analysis result is shown in Table 4.

Table 4-Industrial Concentration of Equipment and Manufacturing Industry in Hebei Province from 2012 to 2015

\begin{tabular}{|ccccc|}
\hline $\begin{array}{c}\text { Industry } \\
\text { category } \\
\text { years }\end{array}$ & $\mathbf{2 0 1 2}$ & $\mathbf{2 0 1 3}$ & $\mathbf{2 0 1 4}$ & $\mathbf{2 0 1 5}$ \\
\hline $\mathrm{CR}_{2}$ & 0.0401 & 0.0835 & 0.0859 & 0.0962 \\
$\mathrm{CR}_{4}$ & 0.0659 & 0.1099 & 0.1131 & 0.1237 \\
$\mathrm{CR}_{8}$ & 0.0940 & 0.1351 & 0.1389 & 0.1484 \\
Source: China Business News 2012 2015 Hebei Province, the list of top 100 manufacturing \\
\hline enterprises
\end{tabular}

From Table 4, the top two enterprises of equipment and manufacturing industry occupy a certain proportion in Hebei Province, and from 2012 to 2015 the proportion is rising, indicating thatthe profitability of the top two enterprises of the equipment and manufacturing industry in Hebei Province maintains rapid growth. Top four and top eight enterprises of equipment and manufacturing industry and the top two enterprises maintain consistent growth, indicating equipment and manufacturing industry ranking top have a strong and rising concentration.

We can see from the value of CR2, automobile manufacturing, electrical machinery and equipment and manufacturing industry are into the top two, and the automobile manufacturing industry is greater than the electrical machinery and equipment and manufacturing industry in 2015. The largest value of CR4 is these two industries, and automobile manufacturing is greater than the electrical machinery and equipment and manufacturing. Automobile manufacturing is not only ranked first, it has also greatly increasedcompared to CR2. We can see from the value of CR8, in equipment and manufacturing industry concentration the ranking is the automobile manufacturing industry, electrical machinery and equipment and manufacturing, metal products industry, railways, ships, aerospace and other transportation equipment and manufacturing, automobile manufacturing and electrical machinery and equipment and manufacturing, all of these are 
higher than the its CR4respectively.

By comparing equipment and manufacturing industry concentration from 2012 to 2015 in Hebei Province, it is not difficult to find that the development of automobile manufacturing industry israpidly steady. Great Wall Motor Co. Ltd. has been ranked the top of equipment and manufacturing enterprises all along in Hebei Province, and the concentration is rising continuously, so we can rely on the company to further strengthen the industrial agglomeration. The concentration of electrical machinery and equipment and manufacturing industry rank the top eight, although a little fluctuation, but the overall concentration of this industry is increased. Jinglong Industrial Group Co., Ltd. operating income For 28.8 billion in 2015, and it can be given full play to its cluster-driven role.The rank of Spring Industrial Group Co., Ltd. metal products industry is not on the top, so the concentration is not too high. General equipment and manufacturing industry only enter the top eight in 2013, so the advantage of concentration is not obvious. The industrial concentration of railway, shipbuilding, aerospace and other transportation equipment and manufacturing industry driven by the iron bridge Group Co., Ltd. is not obvious, but fairly stable, and it can be appropriate for the industrial chain cluster planning.

3.2.2 The analysis of contribution rate of equipment and manufacturing industry concentration rate in Hebei Province

The equipment and manufacturing industry concentration calculated CR2, CR4 and CR8in Hebei Province. We calculate and analyze the growth rate CR2 to CR4 and CR4 to CR8 from $2012 \sim 2015$, that is, thecontribution rate of industrial concentration, as shown in Fig. 1.

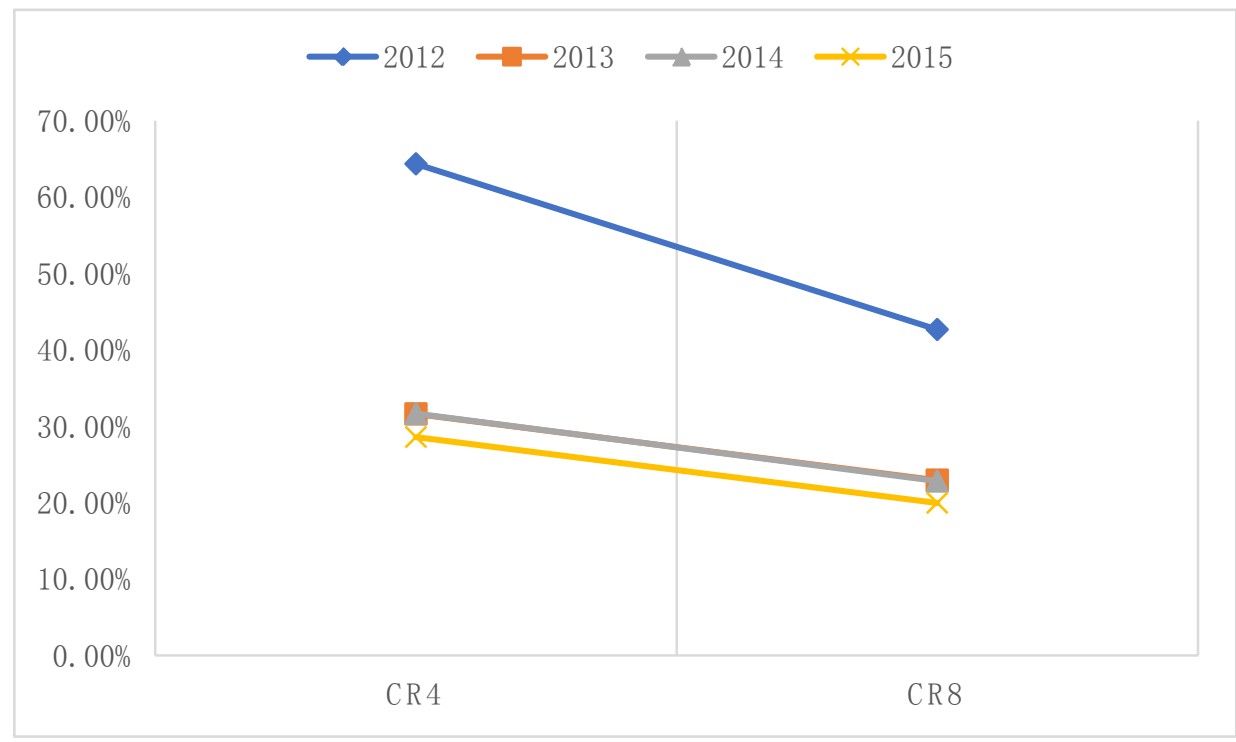

Fig.1-The concentrationgrowth rate of equipment and manufacturing industry in Hebei Province,

It can be seen from Fig.1, 2012 to 2015, the contribution rate of the top two to the top 4 is 
higher than the contribution rate of the top 4 to the top 8 , which shows the top companies is not only large inthe base, the growth rate is also high, andthe enterprise ranking the top is relatively strong in growth ability.

3.2.3Analysis on the annual growth rate of industrial concentration of equipment and manufacturing industry in Hebei Province

After the CR2, CR4 and CR8, this summary calculates and analyzes the growth rate of CR2, CR4 and CR8 in $2013 \sim$ 2015, that is, the annual growth rate of industrial concentration, as shown in Fig. 2.

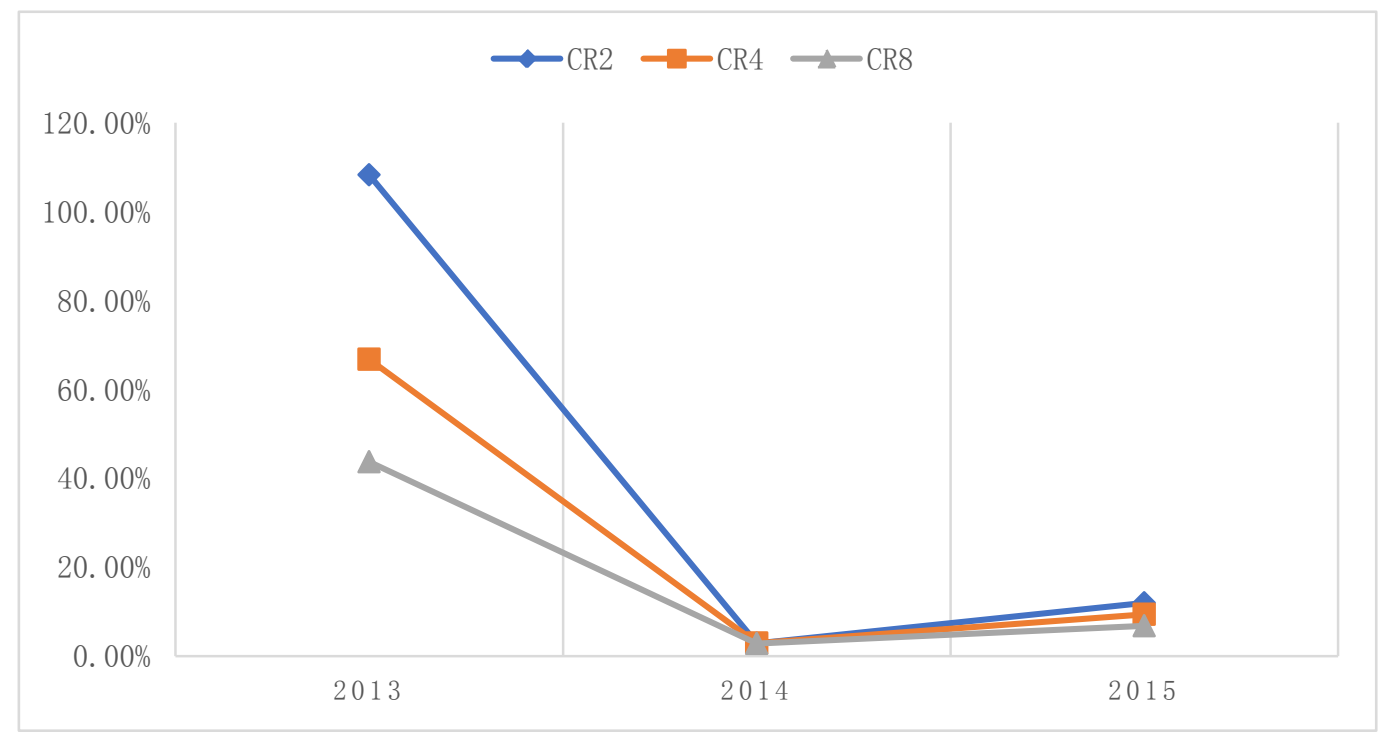

Fig.2-Equipment and manufacturing industry concentration growth rate in Hebei Province in $2013 \sim 2015$

It can be seen from Fig. 2, the concentration rate of industrial concentration of equipment and manufacturing enterprises ranked the top two, the top four and top eight are high in 2013in Hebei Province. The concentration rate of industrial concentration maintains low level 2014 and 2015, which shows that in recent years, equipment and manufacturing industry concentration is lack of the growth capacity inHebei Province. According to comparing CR2, CR4 and CR8 in 2013, we can see that ranking the more backward in the concentration of enterprise industry, the slower the growth rate is, which shows that the more enterprises, theless obvious industry concentration trend, the more difficult to form clusters.

\section{Conclusions and recommendations}

Equipment and manufacturing industry is a long industrial chain industry with high dependence on the industrial agglomerationin Hebei Province. In the future development process, it can consciously rely on high value-added companies to gather upstream and downstream enterprises or strengthen the equipment and manufacturing industry park construction, implementing the preferential policies to attract the industry enterprises to build 
factories or plants.

General equipment and manufacturing industry and special equipment and manufacturing industry cluster began to take shape, and we can strengthen their degree of aggregation in space to obtain higher economies of scale. The spring of the Industrial Group Co., Ltd. as the representative of the metal products industry and the Jinglong Group Co., Ltd. as the representative of the electrical machinery and equipment and manufacturing industry make full use of their capital and continue to strengthen industrial agglomeration to improve their capital utilization. We should strengthen industrial agglomeration of general equipment and manufacturing industry, improve its resource utilization and speed up its capital turnover. The automobile manufacturing industryrepresented by the Great Wall Motor Co., Ltd. and the special equipment and manufacturing industry move the part of the factory and look for low prices land to improve unit profits.

\section{References}

1 Z.Zhao, Y.Hu, Analysis of equipment and manufacturing industry agglomeration degree J. China Soft Science, 2009, (4): 51

2 Research on Export Structure Adjustment of Equipment and Manufacturing Industry in Hebei Province

3 Z.Zhao , Y.Hu ,Analysis of Equipment and Manufacturing Agglomeration J. China Soft Science, 2009, (4): 51-55

4 G.Xiu, M.Fu,Study on Concentration Determination of Industrial Cluster in Equipment and Manufacturing Industry in Heilongjiang Province Based on Location Commercial Law J. Science and Technology, 2014, (2): 16-19

5 Z.Wang , Z.Han, Shenyang City equipment and manufacturing cluster development research J. World Geography Research, 2008, (3): 140-147

6 H.Duan,Study on Simulation of Equipment and Manufacturing Cluster Development in Harbin Based on System Dynamics J; Journal of Harbin Institute of Technology (Natural Science Edition)

7 http://baike.so.com/doc/5384678-5621093.html(28.1.2017)

8 http://baike.so.com/doc/5938060-6150992.html(28.1.2017) 